KAROL SAMSEL

ORCID: 0000-0002-2047-4508

\title{
VADE-MECUM WOBEC ANGLOJĘZYCZNEGO CYKLU POETYCKIEGO DRUGIEJ POŁOWY XIX WIEKU
}

\author{
WSTĘP \\ (ALBO - SKRUPUŁY, WĄTPLIWOŚCI I ROZSTRZYGNIĘCIA)
}

„Syntetyczna komparatystyka” Vade-mecum wydaje się aktywnością intelektualną z góry skazaną na niepowodzenie, czemu doprawdy trudno się dziwić. Cyprian Norwid stworzył dzieło, które - o ile rzeczywiście pojęte jako całość, dysonansowo-polifoniczna całość, jak ujmował cykl swego czasu Rolf Fieguth ${ }^{1}-$ uniemożliwia zaszczepienie w sobie jakiegokolwiek europejskiego lub pozaeuropejskiego tertium comparationis. Vade-mecum jest tekstem niekomparatywnym, jego osobliwy idiomatyzm jest idiomatyzmem spotęgowanym do tego stopnia, że trudno mi sobie wyobrazić, ażeby pełną jedność zestawieniową z tytułem Norwida osiągać można było inaczej aniżeli ex post, tj. już po zapoznaniu się z propozycją poety, mogąc ją w ten czy inny sposób twórczo sparafrazować. Jeżeli jednak uważamy inaczej, zawdzięczamy to w mojej opinii skutecznym symplifikacjom interpretacyjnym, które latami oddziałują na recepcję Norwida i jego cyklu.

Niniejsze wprowadzenie to sygnał, że nie aspiruję poprzez niniejszą wypowiedź do uprawiania - jak ją ująłem - „syntetycznej komparatystyki”, chociaż w zewnętrznym wymiarze mojego badania wydaję się spełniać wszystkie warunki, aby za „syntetycznego komparatystę" uchodzić. „Syntetycznego" - a więc, tak jak rozumiem to słowo - łączącego wiele horyzontów porównawczych w ramach jednej optyki zestawieniowej, którą w moim wypadku stanie się perspektywa anglojęzycznego cyklu poetyckiego drugiej połowy XIX wieku. A interesować

${ }^{1}$ R. Fieguth, Poezja w fazie krytycznej. Cykl wierszy Cypriana Norwida ,, Vade-mecum”, w: tenże, Poezja w fazie krytycznej i inne studia z literatury polskiej, Warszawa 2001, s. 167-172. 
mnie będzie Vade-mecum w świetle (po pierwsze) In Memoriam Alfreda lorda Tennysona, (po drugie) Leaves of Grass Walta Whitmana i (po trzecie) regularnego tomu Poems (1876-1889) Gerarda Manleya Hopkinsa. Wierzę, że ujęcie Norwida w potrojonym (dość nieoczywistym do tego) pryzmacie Tennyson - Whitman Hopkins wyeksponuje nie tylko wewnętrzne antynomie cyklu, lecz także - nieco bliżej określi, czym mógłby być jego „wywrotowy” (jak ujął to Fieguth) monumentalizm. Nie czuję jednak, abym w ten sposób odpowiadał na rzeczowe wezwanie tego badacza do „ustosunkowania cyklów i poematów Norwida do kontekstu polskiego i europejskiego"² z 2008 roku. Tekst, który piszę - pomimo wszystkich zastosowanych tutaj metodologicznych pozorów - nie może być w moim przekonaniu tekstem komparatystycznym, a przynajmniej komparatystyczno-syntetycznym.

\section{STRONA TENNYSONA}

In Memoriam jest dziełem-symbolem wyznaczającym cezurę wielkiego kryzysu religijnego poezji wiktoriańskiej. „Zaraz za Biblią to In Memoriam jest źródłem mego duchowego komfortu", miała powiedzieć Tennysonowi królowa Wiktoria - stojąca obok niego, jak relacjonuje John Barry Steane - z wyrazem „dostojnej niewinności”’3. Jej słowa dają się odczytać w szerszym, rezonującym na cały wiktorianizm kontekście. Tennysona w In Memoriam charakteryzuje bowiem - gdy myślimy o religijnym przekroju cyklu poety - swoista desidajmonia zbliżająca go do takich liberalnych myślicieli religijnych epoki wiktoriańskiej, jak Matthew Arnold, autor „eseju ku lepszemu zrozumieniu Biblii”, Literature and Dogma . Desidajmonia - dodajmy - to brak bojaźni Bożej. Arnold - jak pisze Justyna Pacukiewicz - „stawia się w roli interpretatora instruującego, jak »prawidłowo « czytać Biblię, by stała się źródłem przyjemności”“. I jest w moim przekonaniu coś arnoldowskiego w słynnym zdaniu, które królowa brytyjska skierować miała do Tennysona, jest tutaj coś, co - bez wątpienia przeniesione nieświadomie

${ }^{2}$ R. Fieguth, Ruchy konikiem a łagodne przejścia. Modele ewolucji cyklu lirycznego (na przykładzie J. Kochanowskiego, F. D. Kniaźnina, A. Mickiewicza, C. Norwida), w: Polski cykl liryczny, pod red. K. Jakowskiej i D. Kuleszy, Białystok 2008, s. 26.

3 Thumaczenie moje - K. S. J. B. Steane, 'In Memoriam'. 'Next to the Bible...' (Queen Victoria), w: tenże, Literature in Perspective. Tennyson, London 1966, s. 87.

${ }^{4}$ J. Pacukiewicz, Alfred Lord Tennyson (1809-1892): Oswajanie śmierci, w: taż, Poezja wiktoriańska a wielki kryzys religijny, Kraków 2013, s. 78. „Esej ku lepszemu zrozumieniu Biblii” (An Essay Towards a Better Apprehension of the Bible) to podtytuł Literature and Dogma. 
w rzeczywistość komunikacyjną - mogłoby mimo wszystko posłużyć za stempel epoki, której potrzebom Tennyson za sprawą In Memoriam wyszedł naprzód:

W przeciwieństwie do Carlyle'a, krytykującego w "Signs of the Times” traktowanie religii w kategoriach „zysku”, Arnold wpisuje się w utylitarystyczną myśl epoki i czyni postulat użyteczności Biblii podstawą swojej argumentacji. Celem, dla którego warto się z Biblią zapoznawać, jest radość czytania. God and the Bible zgodnie ze słowami przedmowy została napisana, aby pokazać „prawdę i konieczność Chrześcijaństwa oraz jego urok”, Literature and Dogma natomiast, aby „uzyskać pewne i bezpieczne podstawy służące nieprzerwanemu korzystaniu i cieszeniu się Biblią"

Desidajmonia Arnolda prowadząca go do wyznaczenia eudajmonicznych dróg obcowania z Biblią nie jest jednak desidajmonią Tennysona, któremu o wiele bliżej w psychomachiach 131-ogniwowego cyklu z 1850 roku do Sørena Kierkegaarda aniżeli do chrześcijańskiego liberalizmu. Nie czas tu oczywiście, by dyskutować o możliwym kierkegaardowskim nachyleniu Vade-mecum, hipoteza interpretacyjna tego rodzaju jest jednak ze wszech miar możliwa, zwłaszcza dzisiaj - po studium Elżbiety Lijewskiej tyczącym możliwych śladów obecności ironii egzystencjalistycznej autora Bojaźni i drżenia w Quidamie 6 . W samym Vade-mecum tropienie „widm Kierkegaarda” sprowadzałoby się do szczegółowego prześledzenia sposobów modelowania przez Norwida stanów granicznych podmiotu cyklu w ścisłym związku z postępującą diegezą cykliczną całości utworu.

Rozpatrując Vade-mecum oraz In Memoriam pod względem innowacyjności stylu, nie sposób nie wspomnieć o różnicy stopnia prekursorstwa. Jak podkreśla Laurence Lerner, „In Memoriam umiejscawia się wyraźnie pomiędzy długimi wierszami wczesnego wieku dziewiętnastego a świadomą »kreacją-mozaiką«, z jaką mamy do czynienia w takich nowoczesnych wierszach jak The Waste Land czy Cantos Pounda"7. U Norwida z kolei figura „kreacji-mozaiki” zdaje się już całkowicie oczywista, jest podstawowym, egzegetycznym punktem wyjścia w mówieniu o cyklu, którego ostentacyjna nowoczesność wyraźnie w tym wypadku dystansuje „nieostentacyjną nowoczesność” Tennysona:

Kompozycja cyklu i kompozycja poszczególnych wierszy prezentuje się jako wyjątkowo krucha i hybrydyczna; potencjalnie immanentny w każdym cyklu moment metapoetycki bądź kry-

5 Tamże, s. 80.

${ }^{6}$ E. LijewsKa, Profetyczny ironista na przełomie epok - o możliwych śladach koncepcji ironii Kierkegaarda w poemacie Norwida ,, Quidam”, ,Roczniki Kulturoznawcze” 2016 nr 3 (7), s. 81-99.

7 L. Lerner, Poetry, w: The Victorians. The Context of English Literature, red. L. Lerner, London 1978, s. 26. 
tyczny wobec poezji, jest tu szczególnie podkreślony, intertekstualność otwarcie zademonstrowana, sama w sobie staje się tematem konstrukcji kompozycyjnej ${ }^{8}$.

Należy podkreślić, że to, co określiłem mianem „,nowoczesnej ostentacji” zawartej w samym zamyśle Vade-mecum (czy można tu mówić w ogóle o strukturze cyklu?), doprowadza do niemalże paraliżującego wszelką refleksję sproblematyzowania Norwidowskiego projektu. U „,nieostentacyjnie nowoczesnego” Hopkinsa diegeza cykliczna jest w planie wszystkich 131 ogniw płynna, ciągła oraz stabilna (jedna z pierwszych czytelniczek In Memoriam, Charlotte Brontë nazywa wręcz cykl „,mournfully monotonous”, a więc ,żałośnie monotonnym”), tymczasem u Norwida - linia diegetyczno-asocjacyjna utworu tak dalece ulega permutacjom oraz zaburzeniom, że nasuwa wręcz Fieguthowi myśl, ażeby czytać Vade-mecum anarchistycznie: cyklizacyjno-decyklizacyjnie i decyklizacyjno-cyklizacyjnie.

Cokolwiek by nie mówić o „rozpierzchłej”, a wręcz „odłamkowej” strukturze cyklu Norwida (nawiązuję tu do metafor organizujących u Fiegutha myślenie o niestandardowości cyklu w ogóle), zamysł poety jest w opinii badacza spójny: Norwid pragnie uczynić Vade-mecum cyklem autotematyczno-krytycznym, jeżeli już nie autotematyczno-rewizyjnym (bo ,tak ułożył swój cykl, że kompozycja cykliczna odzwierciedla w poetycki sposób dynamikę i niestabilność samego historycznego procesu poetycznego"9). Tennyson po stracie swojego przyjaciela, Arthura Henry'ego Hallama w 1833 roku, pisze rozległy cykl konsolacyjny, w którym również zawarty został (tak, jak u Norwida) potencjał krytyczno-autotematyczny. Tzw. oswajanie śmierci staje się tu narzędziem dla metafizycznego uzdrowienia znajdującej się w klinczu tematów zastępczych - literatury angielskiej. Justyna Pacukiewicz pisze:

To właśnie język poetycki ma stać się remedium pomocnym w przezwyciężeniu smutku oraz ma przewartościować poetycki model świata w stronę modelu proponowanego przez ontologię chrześcijańską [tu nie wolno nam zapominać o zastrzeżeniu redaktorów anglikańskiego pisma „Christian Remembrancer” na temat Tennysona. Zostało ono sformułowano po wydaniu przez pisarza poematu Princess i brzmiało „No one would call him a Christian poet - za Steane'em: K. S.] ${ }^{10}$.

${ }^{8}$ R. FIEGUTH, Cykl poetycki jako model historycznej ewolucji poetyckiej. , Vade-mecum” Norwida (1866), w: tenże, Rozpierzchte gałąki. Cykliczne i skojarzeniowe formy kompozycyjne w twórczości Adama Mickiewicza, przeł. M. Zieliński, Warszawa 2002, s. 42.

9 Tamże.

10 J. Pacukiewicz, s. 126. Zob. także: J. B. Steane, s. 87. 
In Memoriam jest jednak w pierwszym rzędzie cyklem elegijnym i to na podstawie elegijnej, jak podkreśla Steane, rodzi się u Tennysona wzniosłość, nierzadko dość osobliwa. Co zauważa bowiem np. George Malcolm Young, „w swoim najpodnioślejszym nastroju, Tennyson przemawia czasem niczym archanioł upewniający nas co do tego, że wszechświat zdoła przez to wszystko przebrnąć"11 (w oryginale - it will muddle through). Nadzieja i emocjonalność w wypadkach tego rodzaju stają się dla In Memoriam o wiele bardziej kluczowe niż dla Vade-mecum - skądinąd tak wyraźnie przecież zanurzonego w „poezję uczuć” (co wiele razy podkreślała Danuta Zamącińska ${ }^{12}$ ). Pragnę przy tej okazji wyraźnie podkreślić, że bez widzenia w wielkim cyklu Norwida poezji emocjonalnej, nie byłoby możliwe w ogóle porównywanie Vade-mecum z cyklami, które mnie zainteresowały: Tennysona, Whitmana czy Hopkinsa. Tutaj przyjęcie założenia o emocjonalności wpisanej psychologicznie w doświadczenie podmiotu Vade-mecum wydaje się bowiem wręcz warunkiem sine qua non. Nie oznacza to jednak, że krystalizując emocjonalność swojego podmiotu cyklicznego, Norwid (dążąc np. do regeneracji erodujących wartości absolutnych) jak Tennyson dawałby upust osobliwościom uczuć.

Wartościowe - jak uważam - byłoby zbadanie pod tym względem konsolacyjnego pierwiastka Vade-mecum i jego wkładu w strukturę cyklu. Czym jest - pojęta jako zjawisko wewnątrztekstowe - konsolacyjność Vade-mecum (rozciągająca się od oczywistych przypadków takich, jak wiersz Pamięci Alberta Szeligi Hrabi Potockiego ... po przypadki niezwykle złożone, jak Do Walentego Pomiana Z.) i czy jest to konsolacyjność mogąca w jakikolwiek sposób łączyć się z konsolacyjnością Tennysonowskiego In Memoriam? Zanim to uczynimy, pozostanie refleksja podstawowa - nad elegijnością cyklu Norwida oraz elegijnością cyklu Tennysona. Na gruncie norwidologii najdokładniej opisała tę pierwszą Bernardetta Kuczera-Chachulska. Jej sąd koresponduje z przywoływanym już tu sądem Justyny Pacukiewicz o Tennysonie. Elegijna poetyckość cyklu Norwida i elegijna poetyckość cyklu Tennysona są próbami strukturacji całych zaproponowanych przez poetów konstrukcji wierszowych. Mówiąc poetycko: elegia oraz elegijność przenikają tu strukturę całości i ją - przynajmniej - współdeterminują ${ }^{13}$.

11 J. B. Steane, s. 82.

12 D. ZamącińsKa, Poznawanie poezji Norwida, „Studia Norwidiana” 1: 1983, s. 5-30.

13 B. KuCZera-ChachulsKa, Wokót „, Czarnych...”, „,Białych kwiatów” i ,, Vade-mecum”. Elegijność Norwida, w: tejże, Przemiany form i postaw elegijnych w liryce polskiej XIX wieku. Mickiewicz, Stowacki, Norwid, Faleński, Asnyk, Konopnicka, Warszawa 2002, s. 175-221. 


\section{STRONA WHITMANA}

Walt Whitman ujęty w kontekście Cypriana Norwida i Vade-mecum jest przykładem jeszcze bardziej skomplikowanym niż Alfred Tennyson. W jego polskiej recepcji, którą gruntownie prześledziła Marta Skwara, uderza przede wszystkim krytyka amerykańskiego poety ujawniająca się z całą siłą we wczesnych pismach wydawcy Norwida - Zenona Miriama-Przesmyckiego oraz w esejach Stanisława Brzozowskiego, który jako pierwszy łączy ekstatyczność autora Leaves of Grass z (wydawałoby się) bardzo odległą odeń ekstatycznością autora Vade-mecum: „Gdy Whitman rozsyła pozdrowienia i błogosławieństwa Paryżowi, Europie, wszystkim stanom, całemu światu, wydaje się nam trochę zbyt łatwą ta geograficzna ekstaza”, ,przychodzi nam na myśl ów heroiczny motyl Norwida, który był pewny, że ciągnie poza sobą rydwan świata"14.

Dla Miriama-Przesmyckiego fatalne zauroczenie Whitmana tym, co nazwał Brzozowski „ekstazą geograficzną”, odbiło się na jakości jego cyklów poetyckich uznawanych przez edytora Norwida niemal za grafomańskie. „Jego pseudo-poetyckie rapsodie, wydawane w cyklach ochrzczonych najdziwaczniejszymi tytułami "Źdźbła trawy» (Leaves of Grass) lub »Odgłosy bębna» (Drum taps) gardzą wszelkimi regułami i ograniczeniami rymu, rytmu i metryki"15. Powróćmy jednak do kwestii „ekstazy geograficznej”. Miriam podejrzewa, że jej wizję mógł Whitman sformułować m.in. w oparciu o twórczości Wiktora Hugo, „widzi [tu bowiem] realizację posuniętego do ostatecznych granic stylu proklamacji Wiktora Hugo do Paryża i »otaczającej go kuli ziemskiej«" ${ }^{\text {16 }}$. Skwara przypomina, jak silnie w swoim czasie autor Źdźbet trawy mógł czerpać z estetyki i etyki hugoliańskiej: ,pod koniec życia Whitman zachęcał do porównań swojej poezji z twórczością Hugo, broniąc własnej poetyki. Hugo był dla niego twórcą, który, podobnie jak on sam, starał się wyzwolić literaturę z tabu cielesności” ${ }^{17}$.

Nasuwa się tu w związku z Norwidem wiele istotnych analogii. Wpierw jednak przywołajmy te, które bezpośrednio nawiązują do istoty cykliczności Vade-mecum. Gdy wiele razy już tutaj wspominany Fieguth sygnalizuje konieczność rekon-

${ }^{14}$ Brzozowski własne skojarzenie z Norwidem buduje w oparciu o wiersz Whitmana, Salut Au Monde! M. SKwara, Whitman poetów i pisarzy polskich. Brzozowskiego ,poeta życia”, w: taż, „Polski Whitman”. O funkcjonowaniu poety obcego w kulturze narodowej, Kraków 2010, s. 219.

15 Z. Przesmycki-Miriam, Poeci pótnocno-amerykańscy, „Życie” 1887, nr 19, nr 20, s. 313. Zob. również: M. SKWARA, Whitman poetów i pisarzy polskich. Miriama ,poeta surowy”, w: taż, „Polski Whitman”, s. 164.

16 Tamże.

17 Tamże, s. 164-165. 
strukcji dla Vade-mecum „najbliższych kontekstów literackich europejskich”, myśli w tym na przykład o „obfitej twórczości »cyklicznej« Wiktora Hugo" ${ }^{18}$. Dla Norwida w Dwóch aureolach pisarz - przypomnijmy: „ma nieśmiertelną zaletę, że francuski język podniósł może do ostatecznych wyżyn estetycznych”, , wielkim talentem” dodajmy - ,po-głównie na kontrastach i wytworności opartym” [podkr. moje - K. S.] (VI 534). Czy rzeczywiście dukt wiedzie tu przez Hugo do Whitmana? Otaczanie Ameryki kulą ziemską czy też otaczanie Francji kulą ziemską, sam geografizm i pangeografizm jako wyraz manifestacji twórczego światopoglądu, wszechobejmowania świata poprzez dzieło - wydają się przebijać w figurach wiersza Za wstęp. (Ogólniki). I dałoby się w moim przekonaniu Za wstęp. (Ogólniki) odczytać w duchu hugoliańsko-whitmanowskim, jako specyficzną odpowiedź (świadomą albo mimowolną) daną przez Norwida wyrazicielom osobliwego kultu ,geograficznej ekstazy”.

Zresztą - kiedy czytamy przedmowę do cyklu Leaves of Grass, trudno powstrzymać się od wrażenia, że wsłuchujemy się podwójnie: i w młodego podówczas Whitmana, i niemniej - w Norwida „ducha-Artystę pojącego się jak motyle” - „Wiosną życia”, zmierzającego, aby na swój sposób „odpowiednie dać rzeczy - Słowo". Wiersz Norwida jest bowiem wierszem o wcielaniu się osobowości Artysty w stworzenie. Tą drogą podążając, można niemal tym samym językiem mówić o Za wstęp. (Ogólniki) oraz o whitmanowskiej wizji amerykańskiego barda, poety jako „rozciągającego się" ciała Ameryki. Whitmana i Norwida interesuje bowiem wyczucie, rodzaj transcendentalnego Gefühl, które pozwala mówić we właściwych momentach tak i o „kulistości”, jak o „spłaszczeniu” świata przedmiotowego - a więc żywo reagować na transformacje „ducha kraju” tak, jakby transformowało coś cielesnego i przynależącego biologicznie do artysty. Dopiero rozszerzony poeta-bard, poeta-rapsod może stworzyć u Whitmana cykl. Dopiero rozszerzony w znaczeniu duchowo-cielesnym poeta może „odpowiadać słowem na rzecz". Tyle dokładnie Whitman o artyzmie i artyście, który tłumaczy:

Jego duch odpowiada duchowi kraju, wciela się w geografię kraju i w życie przyrody, i w rzeki, i w jeziora. Missisipi z corocznym wylewem i zmiennym korytem, rzeka Missouri i Columbia, i Ohio, i Rzeka Świętego Wawrzyńca z jej wodospadami, i piękna męska rzeka Hudson - tak samo wpływają w swoje ujścia - wpływają i w niego. [...] Gdyby długie wybrzeża Atlantyku wydłużyły się jeszcze bardziej i wybrzeża Pacyfiku wydłużyły się jeszcze bardziej, to on bez trudu wydłużyłby się wraz z nimi na północ i na południe. On także rozciagga się pomiędzy tymi wybrzeżami od wschodu na zachód i rozważa, co się pomiędzy nimi znajduje [podkr. moje - K. S] ${ }^{19}$.

${ }^{18}$ R. Fieguth, Ruchy konikiem, s. 26.

${ }^{19} \mathrm{~W}$ tłumaczeniu Juliusza Żuławskiego. Za: J. ŻuŁAwski, Pośród źdźbel trawy. Wizja poetyAmerykanina, w: tenże, Wielka podróż Walta Whitmana, Warszawa 1971, s. 64. 
Wróćmy raz jeszcze do Dwóch aureol i do dialektyki „kontrastów i wytworności” w pisarstwie Hugo. Czy zapisując te słowa, miał Norwid może w pamięci własny list sprzed wielu lat - do Józefa Ignacego Kraszewskiego z ok. 15 maja 1866 roku? Wtedy podobnie bardzo opisywał utrwalone w strukturze oraz formie Vade-mecum własne autorskie dążenie: cykl jego (utrzymywał poeta), ,jest opracowany na głębiach prawd i różnostronności form i bogactw języka prześladowanego i podupadłego". Whitman dosyć podobnie do Norwida - jeśli mógłbym tak powiedzieć - nie ma w sobie lęku przed zstąpieniem do otchłani pojęć i znaczeń, nie ma obawy przed katabazą języka, bo (tak samo jak u Norwida) katabaza tego rodzaju dokonywana jest w poszukiwaniu prawdy. Dla autora Quidama jest to zejście do świata znaczeń ,prześladowanych i podupadłych”. Dla Whitmana ten sam ruch stanowić ma część jego transcendentalnego etosu, co dobitnie wyraził w przedmowie do Leaves of Grass rozległym, retardowanym i sugestywnym zdaniem (podaję w przekładzie Juliusza Żuławskiego):

Na żadnym z kontynentów globu, ani na żadnej planecie czy satelicie, czy gwieździe, ani na asteroidach, ani na żadnych obszarach eterycznej przestrzeni, ani pośród zgęszczenia, ani pod płynną cieczą morza, ani w tych warunkach, które poprzedzają rodzenie dzieci, ani w żadnym czasie podczas przemian życia, ani w tych warunkach, które następują po tym, co nazywają śmiercią, ani w żadnym napięciu uśpienia czy późniejszych żywotnych działań, ani w jakimkolwiek procesie formacji czy reformacji, gdziekolwiek by to nie było, nigdy nie osiągnęła dojrzałości istota, która instynktownie nienawidziła prawdy ${ }^{20}$.

I tak jak Norwid potrafi mówić o dwóch twarzach Hugo naraz, tak samo Whitman dopatruje się w każdym obliczu twórców arcydzieł literatury - oblicza janusowego. I jeszcze podobnie bardzo do Arnolda - rozpatruje otwarcie kwestie dwuznaczności ukorzenionych w Biblii, czytając ją np. w kluczu osjanicznym. Pisze o tym Howard J. Waskow:

„Ekonomia” Dantego [Waskowowi chodzi o ekonomię słów - K. S.] jest jednocześnie „skąpa”, „wyzbyta radości” oraz „wspaniała”; Shakespeare’a „rozwlekłości” pozostają na przemian „kwieciste”, „kunsztownie splątane” i „płodne”, mnożące się niczym sama natura. Krytykowane przez Whitmana prace $\mathrm{w}$ jego selekcji nigdy nie są pozostawiane samym sobie. Biblia za jednym razem kojarzona z ,rozproszeniami” oraz „mglistościami” Osjana naraz chwalona jest za ,prostotę”. Natura sama w sobie często wydająca się modelem precyzji oraz równowagi zostaje przywołana dla wyjaśnienia Shakespeare'owskiej nadmiarowości. U Whitmana wszystko bowiem ma dwie twarze ${ }^{21}$.

20 Tamże, s. 66.

21 Tłumaczenie moje - K. S. H. J. Waskow, Whitman's habit of mind. „Bipolar unity” in poetic theory, w: tenże, Whitman. Explorations in Form, Chicago - London 1966, s. 55. 
Bipolarna jedność świata świata, jak zauważa Waskow, jest dla Whitmana źródłem nieustannego optymizmu poznawczego, antynomia z kolei staje się narzędziem teatru person, który Whitman prezentuje ku umoralnieniu czytelnika. Jeśli myśleć o romantycznej personologii, Norwidowi zdecydowanie bliżej w $\mathrm{Va}$ de-mecum jest - jak można podejrzewać - do teatru person Emily Dickinson aniżeli do teatru person Walta Whitmana, gdyż ten drugi - nie ma poczucia, że zstępuje w głąb ,języka prześladowanego i upadłego", nie jest tak, jak Norwid naznaczony kryzysem spełnialności misji literackiej. Nie jest Ezechielem, nie jest prorokiem pustynnym.

$\mathrm{Z}$ tego wynikają podstawowe różnice metafor cyklu polskiego oraz amerykańskiego, do tego być może - regularnie postaciowana przez egocentryczny podmiot całości diegeza cykliczna Źdźbet trawy, oraz przerywana, niewidoczna, niepostaciowana, nieuobecniona, ciągle sprawiająca problemy - diegeza cykliczna podmiotu Vade-mecum. Nie wolno przy tym zapominać, że diegeza Leaves of Grass jest diegezą cyklu, który jest tutaj reprezentowany jako (przynajmniej w jakimś odcinku) funkcja bycia poematem, jeśli nie „wielkim, dynamicznym eposem” Ameryki (jak pisze Żuławski). Triumfalizmowi myślenia Whitmana o cyklu towarzyszy interesująca metaforyka organiczna. Whitman tłumaczy:

Jednolitość poematu doskonałego prowadzi ku swobodnemu rozwojowi praw metrycznych i pączkuje w nim tak bezbłędnie i spontanicznie jak bzy i róże na krzewie, i przybiera kształty tak spoiste jak kształty orzechów czy pomarańczy, czy melonów, czy gruszek, i rozsiewa zapach wymykający się regułom ${ }^{22}$.

Vade-mecum złączone „misterną nicią wewnętrzną” - jak thumaczy się Henrykowi Merzbachowi w korespondencji Norwid - a jeśli wierzyć podmiotowi wiersza Finis - nawet „,nicią logiczną”, jest naszyjnikiem z łez i logicznych, ,międzyperłowych spojeń”, gdzie metaforą nieskończonego skomplikowania jest „logiczne wciekanie łzy we łzę”. Nie wiem, jak Państwo ów naszyjnik sobie wyobrażają, ja jednak zawsze myślę o naszyjniku złożonym z ogromnej liczby barocco (pereł o nieregularnym, fantazyjnym kształcie, z których swoją nazwę wzięła cała epoka). Ten obraz, jak mi się zdaje - bardzo elegijny, a i nieco tennysonowski - warto by przeciwstawić amerykańskiej metaforyce kwietno-owocowej, bo być może najlepszą podstawą mówienia o diegezie cyklicznej jest właśnie jej metafora.

Nie wolno jednak zapominać o tym, że są u Norwida dalekie, pogłosowe wręcz echa Whitmanowskich metafor diegetycznych z Przedmowy do Leaves of Grass. Jeżeli myśleć bowiem o trzech stopniach naturystycznych metafor cyklu, Norwid znajduje się na najniższym trzecim (choć nie jest antywitalistą), podczas gdy

${ }^{22}$ W tłumaczeniu Juliusza Żuławskiego (tenże, s. 65). 
Whitman trafia na najwyższy z progów. Dla tego drugiego przecież proces bycia w cyklu (bycia autora lub czytelnika) - jest procesem wewnętrznego kwitnienia, puszczania soków. Stopień drugi - to widzenie cyklu jako martwej natury, które można nazwać kolekcyjną, jeśli nie kolekcjonerską wizją tworzenia cyklu. Nareszcie stopień trzeci, który poprzez wiersz Finis chciałbym identyfikować z Norwidem, za metaforę organizującą powinien obrać zielnik, bo cały cykl staje się w Finis właśnie „zielnikiem badacza śmierci Tworów”, w czym tkwi rozpoznanie tragizmu takich procesów twórczych, jak cyklotworzenie czy cyklokreowanie. Norwid - można by powiedzieć w planie wielkiej metafory oraz nie mniejszego skrótu myśli - „poskramia” Whitmana smutkiem Tennysona, ale nie wiadomo, czy odnajduje zasłużoną konsolacyjność.

Warto ten cichy, prawie że niesłyszalny lament Norwida nad mumifikującym zasuszeniem cyklu i jego historii należącej już do przeszłości zderzyć z ostentacyjnym fragmentem Whitmanowskiej Przedmowy do Leaves of Grass. Mam nadzieję, że wrażenie pozostanie uderzające, Whitman pisze:

Ameryka nie odrzuca przeszłości ani tego, co przeszłość wytworzyła w dawnych formacjach, między innymi w polityce, w koncepcji kast czy w starych religiach - spokojnie przyjmuje tę lekcję - nie niecierpliwi się aż tak, jak się przypuszcza, że zepsucie ciągle jeszcze czepia się poglądów, obyczajów i literatury, podczas gdy życie, które ich wymaganiom służy, przeszło już w nowe życie nowych form - pojmuje, że zwłoki z wolna wynosi się z jadalnych i sypialnych izb domu - pojmuje, że martwe te zwłoki i jeszcze czas jakiś leżą w drzwiach - że były kimś najsprawniejszym w swoim czasie - ale że działalność tego kogoś przeszła na krzepkiego i kształtnego spadkobiercę, który nadchodzi - i że on będzie swoim czasie najsprawniejszy ${ }^{23}$.

I chyba najbardziej poruszające ze zdań Whitmana, które pojawia się zaraz po zacytowanym przed chwilą fragmencie: „Amerykanie mają chyba najbardziej poetycką naturę spośród wszystkich narodów wszystkich czasów"24. Kiedy to czytam, mam (jako norwidolog) dziwne poczucie, że właśnie tak mógłby przemówić Cezar z Kleopatry i Cezara, widząc dla przykładu królową egipską pożywającą z mumią, bądź w szerszej całości przyglądając się upadającej - trochę dekadenckiej, a trochę nekrofilskiej - kulturze Norwidowskiego Egiptu. I mimo wszystko... chyba nie jest przypadkiem, że tragedia starożytna Norwida powstawała dokładnie w tym samym momencie, w którym Fryderyk Nietzsche publikował swoje pierwsze, legendarne dzieło - Narodziny tragedii z ducha muzyki.

${ }^{23}$ W tłumaczeniu Ludmiły Marjańskiej. Za: J. ŻuŁAWsKI, s. 63.

${ }^{24}$ Tamże. 


\section{STRONA HOPKINSA}

Jak twierdzi Maciej Żurowski, „byłoby dziwne, gdyby religijności Hopkinsa i Norwida, z różnych powodów odmiennej, nie zdarzało się przybierać tej samej tonacji poetyckiej" 25 . Paralelizm - jak rozstrzygała ostatecznie (wiele lat po Żurowskim) Agata Brajerska-Mazur ${ }^{26}$ - oparty został o współtożsamość literackiej ontogenezy w wierszach obydwu poetów: ontogenezy mającej zawierać się w charakterystycznym przede wszystkim dla Hopkinsa chwycie inscape. Wskazywanie na istnienie w poezji Norwida chwytów podobnych do Hopkinsowskiej strategii obrazowania lirycznego pozostaje mimo wszystko (w moim przekonaniu) dość ryzykowne. Za inscape pojętym w kluczu autorskich komentarzy oraz literackich realizacji poety kryje się bowiem dużo głębsza treść niż ta, która wskazywałaby wyłącznie na fakt, że jest to wyłącznie środek artystycznego wysłowienia. Dużo bezpieczniej wydaje się rozważać ten wątek Żurowski, w niespiesznym, eseizującym trybie wykazując silne, lecz niezobowiązujące do dalszej, szczegółowej refleksji podobieństwa pomiędzy Norwidowskim wierszem $W$ pamiętniku (z Tyrteja, 1865-1866) oraz Hopkinsowskim sonetem O tym, że natura jest heraklitejskim ogniem, i o pociesze Zmartwychwstania (1888):

Jego początek, mówi Donald McCheney, przedstawia inscape w typowej postaci - obrazy chmur, świateł i cieni na domach i drzewach objawiają heraklitejską energię natury, ale nie mniejsze znaczenie ma sama praca poety w materii słowa, ,,język podniesiony do wyżyn ekstazy”, ,język dla języka". Należałoby jeszcze dodać, że inscape nie jest całkiem obcy impresjonizmowi, a zarazem wyprzedza teorię imagizmu i epifanie Joyce'a ${ }^{27}$.

Po pierwsze, dla Stanisława Barańczaka, thumacza wierszy poety inscape (to samo, które Brajerska-Mazur dostrzegała u Norwida) to jednak nie tylko chwyt, a metafora organizująca całą intelektualną rzeczywistość poezji Hopkinsa, zwłaszcza obszary filozofii natury i języka. To zaś zupełnie inne ujęcie niż to, które prezentuje Żurowski wiążący strategię obrazowania z imagizmem-impresjonizmem. Inscape dla Hopkinsa znaczy w tym rozleglejszym ujęciu dokładnie tyle - ryzykuje Barańczak śmiałe porównanie - ile haecceitas dla Jana Dunsa Szkota. Porównanie jest śmiałe, owszem, ale wydaje się uzasadnione. Jak tłumaczył William Henry Gardner:

${ }^{25}$ M. Żurowski, Hopkins, Mallarmé $i$ Norwid, „Poezja” 1983, nr 4-5, s. 188.

26 A. BrajersKa-Mazur, Los geniuszów, czyli niezwykle paralelizmy w życiu i twórczości Gerarda Manleya Hopkinsa i Cypriana Kamila Norwida, w: Symbol w dziele Cypriana Norwida, pod red. W. Rzońcy, Warszawa 2011, s. 299-310.

${ }^{27}$ M. ŻurowsKi, s. 189. 
Decydujący wpływ myśli Dunsa Szkota polegał na tym, że „teolog ten jak gdyby dał mu (Hopkinsowi) pozytywną sankcję na ujawnienie swej indywidualności - czego Hopkins nie mógł żadną miarą uczynić jako jezuita, ale co mógł uczynić jako poeta chrześcijański",28.

Spostrzeżenie Gardnera wydaje się wiążące również w perspektywie Norwidowskiego Vade-mecum. Ilekroć bowiem widzieć w obrazowaniu lirycznym polskiego poety reminiscencje Hopkinsonowskiego inscape, tylekroć należałoby chyba wziąć pod uwagę znaczące zastrzeżenie: Norwid nigdy nie wyposażył siebie w taką koncepcję estetyczną, która sublimowałaby koszty wewnętrzne jego przekonań, w tym - sublimowałaby ofiarę z przekonań religijnych. Norwid wreszcie nigdy, tak jak Hopkins Dunsowi Szkotowi, nie zawierzył żadnemu z filozofów - ani wpisującemu się jak Duns Szkot w antytezowanie tomizmu, ani temu, którego charakteryzowałaby tomizmu syntetyzowanie.

Po drugie, właśnie przez wzgląd na to, że inscape nie jest tylko chwytem, lecz także - efektem określonej filozofii języka i natury, Barańczak może postawić na końcu swojego studium uderzającą tezę, jakoby „w wierszach Hopkinsa dawało się dostrzec, głęboką zasadniczą zgodność i odpowiedniość »informacji stematyzowanej « $\mathrm{z}$ »informacją implikowaną«" 29 . U Norwida struktura przekazu lirycznego wydaje się tymczasem dokładnie przeciwna, co starałem się wykazać - przede wszystkim czerpiąc przykłady z charakteryzacji liryki Emily Dickinson i wykazując, że autora Vade-mecum oraz ,,pustelnicę z Amherst” łączy analogiczny sposób użycia funkcji poetyckiej. To kolejne zastrzeżenie w dopatrywaniu się podobieństw Norwidowskiego obrazowania do Hopkinsowskiej strategii opisu: Norwid - kiedy mowa o głębi i skomplikowaniu przekazu lirycznego, w perspektywie anglojęzycznego tertium comparationis - wydaje się bardziej dickinsonowski niż hopkinsowski. Pisałem na ten temat:

Wiersze Cypriana Norwida i Emily Dickinson łączy jedność wypracowanej w swoich tekstach funkcji poetyckiej objawiająca się w tym, by potęgując znaczenie poetyckiej wypowiedzi, nie ujawnić jej erozji wywołanej kosztami nieustannie wznawianego i przeprowadzanego od nowa language-making. Język jest popękany, ale Jakobsonowska funkcja poetycka, o ile - rzecz jasna - zostanie zrealizowana autorsko - przez Dickinson albo Norwida, ma za zadania tak go

${ }^{28}$ S. BARAŃCZaK, Wstęp. Nieśmiertelny diament, w: G. M. Hopkins, 33 wiersze, wybór, przekład, wstęp i opracowanie S. Barańczak, Kraków 1992, s. 10. Odmienne spojrzenie na kwestię przedstawia Christopher Devlin, który sugeruje, że „filozof i poeta skonfrontowali się ze sobą raczej jako towarzysze-pielgrzymi w drodze (fellow-pilgrims) niż jako mistrz z uczniem”. Tłumaczenie moje - K. S.: Ch. Devlin, Hopkins and Duns Scotus (1936), w: Gerard Manley Hopkins „Poems”. A Casebook, ed. by M. Bottrall, Macmillan Press Ltd 1975, s. 116.

29 S. BARAŃCZAK, s. 21. 
wyostrzyć, aby szczeliny i wyrwy pozostawały nie tylko niewidoczne, ale „wypełnione” materiałem zastępczym ${ }^{30}$.

Reasumując, to, co łączy Norwida z anglojęzyczną semantyką poetycką, to w moim przekonaniu nie dość liniowa jedność informacji „stematyzowanej” z ,implikowaną” (w tym działający na rzecz takowej jedności chwyt inscape), ale wyrafinowana, ujednolicająca tendencja semantyzacyjna - przeciwstawiająca się na różne sposoby erozji klasycznych, poetyckich semantyk. Nie jest jednak tak, że Hopkins nie znajduje u Norwida żadnych pól podobieństwa (kosztem Dickinson). Aby dowieść jednak, że jest inaczej, należałoby powrócić do jego programu teoretycznego.

Po trzecie bowiem, „nadreprezentowany” w pracach o Hopkinsie inscape nie wypełniłby swojej roli przedstawiającej bez oddziaływania tak zwanego instress. Dopiero „te dwa terminy - podkreśla Barańczak - odegrają podstawową rolę nie tylko dla kształtowania się pojęć Hopkinsa na temat świata natury, ale także dla formowania się jego teorii poetyckiej"31.

Z perspektywy instress Hopkins jawi się już dużo bardziej jako imażynista avant la lettre. Jest również w swoich poszukiwaniach formalnych (i dzięki nim) bliższy wieloaspektowemu Norwidowi, w tym jego poetyckiej summie, Vade-mecum. Swój termin wyposaża bowiem poeta w osobliwą - tak utrzymuje Barańczak - energetystyczno-egzystencjalną wykładnię: ,,instress (dosłownie: nacisk, ciśnienie skierowane do wewnątrz) oznacza komplementarne pojęcie energii egzystencjalnej, która określa i porusza do życia inscape ${ }^{\text {"32 }}$. W tym właśnie duchu - dialektyki instress z inscape dałoby się odczytać jeden z najbardziej monumentalnych rytmicznie oraz architektonicznie wierszy Hopkinsa, Katastrofa statku „,Deutschland”. Podobieństwo z Norwidem, jakie odsłania się w tym przypadku, może wieść w głąb Vade-mecum w moim przekonaniu tylko w jednym kierunku - Fortepianu Szopena.

Już w 1935 roku było dla Bernarda Kelly’ego zupełnie oczywiste, że ,czytanie Katastrofy statku ,Deutschland” bez specjalnego przygotowania się na działanie »masy duchowej « tego tekstu pozbawione jest najmniejszego sensu"33. Kelly wykazywał, w jaki sposób wpisanie przez Hopkinsa własnego arcywiersza w strukturę

${ }^{30}$ K. Samsel, Persona liryczna w wierszach Cypriana Norwida i Emily Dickinson, „Przegląd Humanistyczny" 2017, nr 4 (459), s. 96.

31 S. BARAŃCZAK, s. 9.

32 Tamże.

${ }^{33}$ B. Kelly, 'The Wreck of »Deutschland «' (1935), w: Gerard Manley Hopkins „Poems". A Casebook, s. 117. 
pasyjną determinuje inteligibilność tekstu przyjmowanego - mówiąc w uproszczeniu - wszystkimi zmysłami i pełnią intelektu. Mówiąc nieco subtelniej, pasyjność w strukturze poetyckiej łączyła się w Katastrofie statku „Deutchland” na zupełnie idiomatycznych prawach z transcendentalną jednością apercepcji ${ }^{34}$. Podobnymi prawami synestezji sensualno-intelektualnej wydaje się rządzić Fortepian Szopena i podobną rolę w uzyskiwaniu tego rodzaju synestezji odgrywa w nim pasyjność, co starałem się dowieść w oddzielnym studium ${ }^{35}$.

Na szeregowanie podobieństw pomiędzy arcywierszami Norwida i Hopkinsa może mieć również wpływ fakt, że oba teksty stanowią szczyty rytmiczności oraz muzyczności poetyckiej stylu obu autorów. Barańczak (dla przykładu) za najwybitniejsze osiągnięcie rytmizacyjne uznaje w wierszach Hopkinsa tzw. sprung rhythm ${ }^{36}$. Pewne podobieństwo do sprung rhythm zdradzać mogą również jednak zabiegi transakcentacyjne w Fortepianie Szopena. W studium o „domniemywanej” pasyjności wiersza Norwida starałem się wykazać, że mechanizm owych transakcentacji jest charakterystycznym dla pasji kantatowo-oratoryjnych mechanizmem nierozwiązanego dysonansu septymy wielkiej, tzw. figurą parrhesia ${ }^{37}$.

\section{ZAKOŃCZENIE}

Umieszczenie Vade-mecum w anglojęzycznym trójkącie trzech stron: cyklów poetyckich Tennysona, Whitmana oraz Hopkinsa prowadzi do osobliwych - nie tyle wniosków, co przypuszczeń. Po pierwsze - sceptyczny ogląd zaproponowany we wstępie warto by zniuansować. Rzecz nie w tym, że „syntetyczna komparatystyka" Vade-mecum jest niemożliwa, a raczej w tym, że wywołuje ona bezsilność - tak syntetystów, jak i komparatystów. Z tego z kolei, że nie jest to bezsilność kompetencyjna, łatwo wyciągnąć (fałszywe) wnioski o „niekomparatywności” Vade-mecum w ogóle. Norwidowskie Vade-mecum wymaga tymczasem nie tyle nowego typu komparatystyki literackiej, co nowego mechanizmu porównywania: można by powiedzieć - komparatystyki warunkowej, w której utrzymuje się istot-

34 Tę jedność Hopkins jednakowoż raczej zdaje się estetyzować - niżeli intelektualizować. „A simultaneous delight of the intelligence and the senses”, pisze na ten temat Kelly, czyli „równoczesny zachwyt inteligencją i zmysłami”. Tamże, s. 123.

35 K. Samsel, Domniemany pasyjny aspekt „Fortepianu Szopena” Cypriana Norwida, w: Kantata - oratorium - pasja. Odmiany form literacko-muzycznych w kulturze XVIII i XIX wieku, pod red. A. Borkowskiej-Rychlewskiej i E. Nowickiej, Poznań 2019, s. 123-132.

${ }^{36}$ S. BARAŃCZAK, s. 30.

${ }^{37}$ K. SAmsel, Domniemany pasyjny aspekt, s. 127. Zob. w związku z tym: J. CHOMIŃsKi, K. WilkowsKa-ChomińsKa, Pasja, w: tychże, Wielkie formy wokalne, t. 5, Kraków 1984, s. 447. 
ność oraz integralność tertium comparationis pomimo nawet uchylania ważności opozycji tego, co jest komparatywne, a co komparatywne nie jest (to przeciwstawienie w przypadku tak idiomatycznej twórczości nie powinno być w moim przekonaniu dłużej rozpatrywane).

Przykład mojego zestawieniowego studium Norwid - (Tennyson - Whitman Hopkins) ilustruje naturalnie moje własne modus operandi: ażeby zawiesić opozycję: komparatywne - niekomparatywne, zmierzam raczej w stronę komparatystyk wielu innych rodzajów niż standardowa, syntetyczna. Wykorzystywałem toteż we fragmentach niniejszej pracy zarówno komparatystykę analityczną, jak i metody mikrofilologiczne (mikroanaliza, mikrosynteza, mikroanaliza-mikrosynteza). To wszystko w połączeniu z wrażliwością intertekstualno-interdyscyplinarną może zaowocować udzielaniem tymczasowych przynajmniej odpowiedzi na pytanie o intertekstualny kształt owych „stu poezji dorywczych” (PWsz IX 386) - „stu argumentów” (PWsz IX 217).

\section{BIBLIOGRAFIA}

BarańczaK S., Wstęp. Nieśmiertelny diament, w: G. M. Hopkins, 33 wiersze, wybór, przekład, wstęp i opracowanie S. Barańczak, Kraków 1992.

BrajersKa-Mazur A., Los geniuszów, czyli niezwykłe paralelizmy w życiu i twórczości Gerarda Manleya Hopkinsa i Cypriana Kamila Norwida, w: Symbol w dziele Cypriana Norwida, pod red. W. Rzońcy, Warszawa 2011.

Chomiński J., Wilkowska-Chomińska K., Pasja, w: tychże, Wielkie formy wokalne, t. 5, Kraków 1984.

Devlin Ch., Hopkins and Duns Scotus (1936), w: Gerard Manley Hopkins „Poems”. A Casebook, edited by M. Bottrall, Macmillan Press Ltd 1975.

FIEGUTH R., Cykl poetycki jako model historycznej ewolucji poetyckiej. „Vade-mecum” Norwida (1866), w: tenże, Rozpierzchte gałąki. Cykliczne i skojarzeniowe formy kompozycyjne w twórczości Adama Mickiewicza, przeł. M. Zieliński, Warszawa 2002.

Fieguth R., Poezja w fazie krytycznej. Cykl wierszy Cypriana Norwida „Vade-mecum”, w: tenże, Poezja w fazie krytycznej i inne studia z literatury polskiej, Warszawa 2001.

FIEGUTH R., Ruchy konikiem a łagodne przejścia. Modele ewolucji cyklu lirycznego (na przykładzie J. Kochanowskiego, F. D. Kniaźnina, A. Mickiewicza, C. Norwida), w: Polski cykl liryczny, pod red. K. Jakowskiej i D. Kuleszy, Białystok 2008.

Kelly B., 'The Wreck of »Deutschland “' (1935), w: Gerard Manley Hopkins, „Poems”. A Casebook, edited by M. Bottrall, Macmillan Press Ltd 1975.

Kuczera-Chachulska B., Wokót „,Czarnych...,”, ,Białych kwiatów” i „,Vade-mecum”. Elegijność Norwida, w: taż, Przemiany form i postaw elegijnych w liryce polskiej XIX wieku. Mickiewicz, Słowacki, Norwid, Faleński, Asnyk, Konopnicka, Warszawa 2002.

LiJewska E., Profetyczny ironista na przełomie epok - o możliwych śladach koncepcji ironii Kierkegaarda w poemacie Norwida „, Quidam”, „Roczniki Kulturoznawcze” 2016, nr 3 (7). 
Pacukiewicz J., Alfred Lord Tennyson (1809-1892): Oswajanie śmierci, w: taż, Poezja wiktoriańska a wielki kryzys religijny, Kraków 2013.

Przesmycki-Miriam Z., Poeci pólnocno-amerykańscy, „Życie” 1887, nr 19, nr 20.

Samsel K., Persona liryczna w wierszach Cypriana Norwida i Emily Dickinson, „Przegląd Humanistyczny" 2017, nr 4 (459).

Samsel K., Domniemany pasyjny aspekt „Fortepianu Szopena” Cypriana Norwida, w: Kantata - oratorium - pasja. Odmiany form literacko-muzycznych w kulturze XVIII i XIX wie$k u$, pod red. A. Borkowskiej-Rychlewskiej i E. Nowickiej, Poznań 2019.

SKWARA M., Whitman poetów i pisarzy polskich. Brzozowskiego „,poeta życia”, w: taż, „Polski Whitman”. O funkcjonowaniu poety obcego w kulturze narodowej, Kraków 2010.

SKWARa M., Whitman poetów i pisarzy polskich. Miriama „,poeta surowy”, w: taż, „Polski Whitman”. O funkcjonowaniu poety obcego w kulturze narodowej, Kraków 2010.

Steane J. B., 'In Memoriam'. 'Next to the Bible...'(Queen Victoria), w: tenże, Literature in Perspective. Tennyson, London 1966.

Waskow H. J., Whitman's habit of mind. „Bipolar unity” in poetic theory, w: tenże, Whitman. Explorations in Form, Chicago - London 1966.

ZamąciŃsKa D., Poznawanie poezji Norwida, „Studia Norwidiana” 1:1983.

ŻuŁAwski J., Pośród źdźbet trawy. Wizja poety-Amerykanina, w: tenże, Wielka podróż Walta Whitmana, Warszawa 1971.

Żurowski M., Hopkins, Mallarmé i Norwid, „Poezja” 1983, nr 4-5.

\section{$V A D E-M E C U M$ WOBEC ANGLOJEZZYCZNEGO CYKLU POETYCKIEGO DRUGIEJ POŁOWY XIX WIEKU}

\section{Streszczenie}

Celem studium jest zainicjowanie rozważań nad systemowymi sposobami czytania Vade-mecum, które zarazem stanowić mogłyby punkt wyjścia do uporządkowania porównawczego namysłu nad cyklem i jego prekursorstwem. Możliwości lektury podobnego typu wydaje się stwarzać tzw. komparatystyka syntetyczna i to w jej duchu ustanawiana jest w niniejszym artykule podstawowa linia zestawiania, a także porównywania: Vade-mecum z In Memoriam Alfreda Tennysona, Leaves of Grass Walta Whitmana, a także Poems Gerarda Manleya Hopkinsa. Rezultatem konfrontowania tych ujęć stają się konkretne wnioski, m.in. silna tendencja semantyzacyjna cyklu obecna zarówno u Norwida, jak i u Tennysona, Whitmana albo Hopkinsa, a także eksperymenty w zakresie utrzymywania i zrywania ciągłości diegezy cyklu pojętego jako całość, widocznie zarysowujące się w obrębie cyklów Norwida i Whitmana. Badanie i porównywanie aspektów strukturalnych cyklów Norwida, Tennysona, Whitmana oraz Hopkinsa może wieść w kierunku ostrożnego ustalania nowego punktu wyjścia w badaniach: komparatystyki, którą można by naraz określić mianem warunkowej i analitycznej.

Słowa kluczowe: Vade-mecum; In Memoriam; Leaves of Grass; Poems; cykl poetycki; komparatystyka. 


\title{
VADE-MECUM IN RELATIONS TO THE ENGLISH-WRITTEN POETRY CYCLES OF THE SECOND HALF OF THE XIX CENTURY
}

\begin{abstract}
Summary
The aim of the study is to initiate the considerations over the systemic ways of Vade-mecum's reading that at the same time may determine the new starting point to rearrange the comparative reflection on the cycle and its precursorship. Possibilities of reading as such seem to be given by so called synthetic comparatistics, and in that spirit there is being coinstuted the basic line of compilating and comparing - Vade-mecum with Alfred Tennyson's In Memoriam, Walt Whitman's Leaves of Grass as well as Gerard Manley Hopkins's Poems. The result of confronting of those perspectives have been expressed in specific conclusions, among others the strong cycle's semanticising tendency in Norwid's, Tennyson's, Whitman's and Hopkins's cases and, after all, the experiments in the area of maintaining and breaking the continuity of cycle's diegesis - clearly outlined within the Norwid's and Whitman's cycles. Studying as well as comparing the structural aspects of cycles of Norwid, Tennyson, Whitman and Hopkins may lead to the cautious fixing the new point zero of research - literary comparatistics, which could be named the conditional and analytical ones.
\end{abstract}

Key words: Vade-mecum; In Memoriam; Leaves of Grass; Poems; poetic cycle; comparatistics.

Transleted by Karol Samsel

KAROL SAMSEL - dr hab., adiunkt w Zakładzie Literatury Romantyzmu Wydziału Polonistyki UW. Od 2019 roku kieruje Pracownią Historii Dramatu 1864-1939. Finalizuje doktorat na Wydziale Filozofii UW. Autor książek Norwid - Conrad. Epika w perspektywie modernizmu (2014), Inwalida intencji. Studia o Norwidzie (2017), współredaktor tomów Uniwersalność komizmu. Aleksander Fredro w 220. rocznice urodzin (2015), Poeci-studenci podziemnego Uniwersytetu Warszawskiego wobec romantyzmu (2018) i Dramaty Cypriana Norwida. Teksty - konteksty - interteksty (2019). Aktualnie (obok badań nad twórczością Cypriana Norwida i jej odbiorem) zajmuje się m.in. zagadnieniami polskiego zaplecza pisarstwa Josepha Conrada, w tym zwłaszcza problematyką polskoromantycznej intertekstualności jego pism. Publikował w „Pamiętniku Literackim”, „Studiach Norwidianach”, ,Y Yearbook of Conrad Studies (Poland)”, „Pracach Filologicznych. Literaturoznawstwie” oraz „Filo-Sofiji”. 